2014 Global Marketing Conference at Singapore Proceedings: 137-148(July 2014) http://dx.doi.org/10.15444/GMC2014.01.07.03

\title{
INVESTIGATING CONSUMER IMPULSE BUYING CHOICE IN VARIOUS SITUATIONS- A CROSS-CULTURAL STUDY ON THE CONSUMERS FROM THE UK AND TAIWAN
}

\author{
Jenny Ma, University of Worcester, $\mathrm{UK}^{1)}$
}

\begin{abstract}
This paper examines consumer impulse buying choice in various situations. A questionnaire was sent to 414 consumers in the UK and Taiwan. The results demonstrate the interactions between the consumption situations and corresponding individual-related factors. Individuals' cultural backgrounds were also found to predict different types of impulse buying patterns effectively.
\end{abstract}

Keywords: Impulse Buying, Situational Influences, Cross-Cultural, Individualism, Collectivism

\section{PURPOSE OF STUDY}

This study examines the cross-cultural comparisons on consumer impulse buying choice in various consumption situations and the factors that lead to these choices. Although impulse buying bebaviour has been studied in various cultural contexts, one of the knowledge gaps in the literature is that this specific consumer behaviour has not been examined and compared in different shopping situations. This study intends to complement the impulse buying research by adding more cross-cultural evidence, especially to the topic of context-specific impulse buying choice.

\section{THEORETICAL BACKGROUND}

Cross-cultural comparison has been a significant topic in consumer research and has been investigated concerning a variety of topics. The impulse buying literature also calls for cross-cultural studies as researchers argue that most existing frameworks of impulse buying are developed and investigated from the perspective of Western culture, and of the US in particular (Kacen \& Lee, 2002; Mai, Kwon, Lantz, \& Loeb, 2003).

As several studies have provided an insight into impulse buying behaviour in countries such as China (Zhou \& Wong, 2004; Yu \& Bastin, 2010) and Vietnam (Mai et al., 2003), most impulse buying studies can still be described as country-specific research. The impulse buying literature could still benefit, however, from more cross-cultural comparison studies (Kacen \& Lee, 2002; Lee \& Kacen, 2008). The most significant

\footnotetext{
1)j.ma@worc.ac.uk
} 
works on cross-cultural impulse buying behaviour are by Kacen and Lee (2002). They conducted survey studies in five countries and find that consumers from individualist countries such as Australia and the US engage in more impulse buying than consumers from collectivist countries such as China (Hong Kong) and Malaysia. However, this study has only focused on comparing the impulse buying traits of cross-cultural consumers. The way in which these traits contribute to various patterns of impulse buying behaviour across cultures has remained unknown.

Researchers describe impulse buying behaviour as an unplanned and sudden buying act in response to subjective or external stimuli; and it is a reflection of impulsivity traits, sociocultural values and buying beliefs (e.g. Rook, 1987; Kacen \& Lee, 2002; Xiao \& Nicholson, 2012). It suggests that consumer impulse buying choice is a result of a series of factors, including individual traits and situational factors. Regarding the individual factors of impulse buying, impulse buying tendency has become the most used indication of an individual's impulse buying behaviour. While several previous impulse buying researchers have assumed that the impulse buying tendency is consistent across various situations (Rook \& Fisher, 1995; Beatty \& Ferrall, 1998), some studies have also shown that there can be situational influences that have an effect on impulse buying behaviour. For instance, one study shows that consumers are more likely to buy on impulse and spend more money when they experience self-regulatory depletion (Vohs \& Faber, 2007). Impulse buying researchers therefore suggest that further research should investigate the impulse buying tendency in different shopping situations, in order to generate the behaviour (Jones, Reynold, Weun, \& Beatty, 2003).

One of the knowledge gaps in the existing impulse buying literature is that this specific consumer behaviour has not been examined and compared in various shopping situations. Most research has focused on investigating impulse buying behaviour in certain specific situations (Herabadi, Verplanken, \& Van Knippenberg, 2009). Researchers have investigated impulse buying in several specific shopping environments, such as supermarkets (Kollat \& Willet, 1967; Abratt \& Goodney, 1990; Mai et al, 2003; Zhou \& Wong, 2004), shopping malls (Weun et al, 1998; Phau \& Lo, 2004) and airports (Crawford \& Melewar, 2003). Although researchers argue that impulse buying behaviour is influenced by situational factors (Verplanken \& Herabadi, 2001; Vohs \& Faber, 2007), and it is commonly understood that routine food shopping in a supermarket is different from a shopping trip to a mall, the way in which individuals make impulse buying choice in different consumption situations has not yet been examined. By taking the individual cultural background and context-specific impulse buying choice into account, this study can contribute to a better understanding of impulse buying behaviour in a specific social environment and the ways in which impulse buying behaviour is presented by a group of members of this social environment.

This study is aimed to investigate impulse buying choice within both British and Taiwanese populations. The UK is rated as a more individualist country, while Taiwan is a more collectivist society (Spector, Cooper, \& Sparks, 2001). This study thus examines the way in which impulsivity traits, impulse buying tendency, and other factors lead to 
the UK and Taiwanese consumers' impulse buying choice in various consumption situations. Based on the previous literature, this study has developed the study propositions below:

Study Proposition 1: There will be cultural differences in consumers' impulse buying choice. British consumers will make more impulse buying choices than Taiwanese consumers.

Study Proposition 2: British consumers will exhibit higher impulsivity traits and higher impulse buying tendency than Taiwanese consumers.

\section{METHOD}

A survey was used to collect primary data from British and Taiwanese convenience samples. The questionnaire was originally designed in English then translated to Chinese for the Taiwanese participants using the back-translation method. The translation procedure found that there was no significant difference in the choice of words for most of the measurement scales. Finally, a bilingual researcher reviewed and validated the final result of the translation. The total sample size of 414 includes 201 British and 213 Taiwanese respondents with four age categories from over 18 to 25, 25-35, 35-50, to over 50 (see Table 1).

\section{Measurement}

This study is aimed to examine consumer impulse buying choice in various situations and the factors that contribute to the choice. Therefore, the measurements in this study include demographic questions, UPPS (impulsivity traits), IB tendency, and IB choice in various scenarios.

The UPPS impulsivity scale short form (Whiteside \& Lynam, 2001; Keye, Wilhelm, \& Oberauer, 2009) is used in this study to measure individuals' impulsivity traits. UPPS has been widely used to examine various forms of impulsive behaviour, such as drinking (Magid \& Colder, 2007) and cigarette craving (Billieux, Van der Linden, \& Ceschi, 2007). Furthermore, the UPPS scale examines the different facets of impulsivity, which may be promising for investigating the various types of impulse buying behaviour in this study. The UPPS short form consists of 20 items, which measure 4 facets of impulsivity, including urgency (e.g. I have trouble controlling my impulses), lack of premeditation (e.g. I usually make up my mind through careful reasoning), lack of perseverance (e.g. I finish what I start) and sensation seeking (e.g. I would enjoy parachute jumping). Each facet has items for the respondents to rank from "not true at all" $=1$ to "very true" $=4$. The final Cronbach's Alpha for each scale in this study is: 0.792 for urgency, 0.783 for premeditation, 0.979 for perseverance, and 0.798 for sensation seeking.

The IB tendency scale chosen for this study was developed and validated by Rook and Fisher (1995), and it represents a consumers' attitude towards impulse buying (Coley \& Burgess, 2003). These 9 items of IB tendency are measured on 5-point strongly agree to strongly disagree scales. The items include "I often buy things spontaneously". The 
Cronbach's Alpha for this scale is 0.772 in this study, while Rook and Fisher (1995) documented as 0.88 .

Eight scenarios were given to the respondents in the questionnaire. After the description of the scenarios, the respondents were asked to tick "yes" or "no" to answer the question "Would you buy on impulse now?". These eight scenarios were designed according to the Foxall's Behavioural Perspective Model Matrix (e.g. Foxall \& Greenley, 1999; Foxall \& Yani-De-Soriano, 2005), which categorizes shopping situation based on four types of purchase behaviour: maintenance (e.g. routine shopping in a supermarket), accumulation (e.g. private collection), hedonism (e.g. day-out shopping trip), and accomplishment (e.g. luxury shopping) (see Table 2).

The data distribution was examined by both visual statistical methods. Whilst the histogram and the Q-Q Plot showed that the data could be normally distributed, the Kolmogorov-Smirnov method indicated that the variables do not fit normal distribution $(\mathrm{p}<0.000)$. Therefore, this study uses nonparametric tests such as Mann- Whitney examine the data. Crosstab Chi-square is used to address the study proposition 1 (see Table 3), while Mann-Whitney is conducted to examine the study proposition 2 in this study (see Table 4). Binary logistic regression is also used to predict what factors could lead to impulse buying choice in different situations (see Table 5).

\section{RESULTS}

The findings of this study illustrate that individuals' impulse buying choice varies across different consumption situations. Moreover, the findings reveal that different situations also lead to distinct impulse buying rates. This suggests that the impulse buying tendency, although it is a good indicator of impulse buying behaviour overall, does not necessarily have a consistent effect on impulse buying behaviour across all situations, as former researchers assumed. This study found that the situation of "routine shopping in supermarket" is the situation that prompts impulse buying behaviour most often. $49.7 \%$ of Taiwanese respondents indicated their impulse buying choice in this situation, while this figure is even $\mathbf{9 7 . 5 \%}$ for the British respondents. Among all the tested situations, "credit card point rewards", was found to be the situation with the lowest impulse buying rate. The results of Binary logistic regression further demonstrate the interactions between the consumption situations and their corresponding individual-related factors, including individuals' cultural background.

British consumers were found to make more impulse buying choices than Taiwanese consumers in more situations and seem to be the more impulsive shoppers in this study. Not only did they report a higher IB tendency, they also have a higher level of sensation seeking. This could suggest that impulse buying behaviour is a more common shopping pattern for British consumers in their daily lives. This result corresponds to previous studies that found that consumers from individualist countries engage in more impulse buying than consumers from collectivist countries (Doran, 2002; Kacen \& Lee, 2002). Overall, British consumers are more likely to engage in impulse buying in this study, as 
they report a higher IB tendency and make more impulse buying choices in the designed situations. The findings also show that different facets of UPPS correspond to consumer impulse buying choices within specific situations. Sensation seeking is found to correlate positively with the consumer impulse buying choice in situations of "private collection" and "bar last call". Since the results show that British respondents in this study have higher sensation-seeking scores, British respondents are therefore found to be more impulsive in the above situations.

Taiwanese consumers made more impulse buying choices than British consumers only in two closed-setting situations- an inescapable shopping trip and high-end dining, in which consumers are under greater pressure from physical, social and verbal factors to conform to a particular pattern of behaviour (Foxall \& Greenley, 1999). The fact that more Taiwanese consumers engage in impulse buying in these two situations could suggest that the presence of peers is one important factor acting upon Taiwanese consumers' impulse buying. It could also imply that the impulse buying choice of Taiwanese consumers may be more influenced by the external settings, such as atmosphere.

\section{RESEARCH LIMITATION}

One limitation is that the impulse buying choice was examined in the consumption situations designed by the researcher, rather than actual consumption situations on the spot. Although previous literature provides a theoretical base for the design of situations in this study (Foxall \& Greenley, 1999; Foxall \& Yani-de-Soriano, 2005), when the respondents read the designed situations, it is possible that they incorporated their own personal experiences that were unknown to the researchers. Another limitation of this research is that the UK and Taiwan samples were not identical in terms of age profile due to the non-probability sampling used in this research. Future research is recommended to target a specific age group in different countries in order to provide further cross-cultural comparison in impulse buying behaviour.

\section{PRACTICAL IMPLICATION}

This study provides practical implications for international service providers and retailers, as the results have suggested the way in which a consumption situation should be designed in order to attract consumers from different cultural background. For instance, Taiwanese consumers are found to be more impulsive in closed-setting situations such as" high-end dining" and "inescapable shopping trip"; therefore, creating appropriate physical and social factors in the setting would be effective for encouraging Taiwanese consumers' impulse buying behaviour. For individualist consumers, such as British consumers, impulse buying behaviour has been shown to be a common shopping pattern in the routine shopping situation. In-store offers as marketing strategy might work more effectively on British consumers than Taiwanese consumers. 


\section{SOCIAL IMPLICATION}

This study offers managerial implications for policy makers and consumers. It is beneficial for consumers to understand that their own impulse buying behaviour can be predicted and controlled by being aware of the consumption situations and individual's impulsivity trait. As urgency is often found to be a strong indicator of several problematic or additive behaviours, including tobacco craving (Billieux et al., 2007) and compulsive buying (Billieux, Rochat, Rebetez, \& Van der Linden, 2008), individuals who have higher urgency scores should be aware of certain consumption situations in order to monitor their impulse buying behaviour. For Taiwanese consumers, policy makers should be aware of the strong social influences on consumers' impulse buying behaviour.

\section{CONTRIBUTION}

As the first study to investigate cross-cultural consumer impulse buying choice in various situations, this study contributes to the literature by providing empirical evidence of situational influences and cultural differences.

\section{REFERENCES}

ABRATT, R. \& GOODEY, S. D. (1990). Unplanned Buying and In-Store Stimuli in Supermarkets. Managerial and Decision Economics, 11, 111-121.

BAUMEISTER, R. F. (2002). Yielding to Temptation: Self-Control Failure, Impulsive Purchasing, and Consumer Behavior. Journal of Consumer Research, 28, 670-676.

BEATTY, S. E. \& ELIZABETH FERRELL, M. (1998). Impulse buying: Modeling its precursors. Journal of Retailing, 74, 169-191.

BILLIEUX, J., GAY, P., ROCHAT, L. \& VAN DER LINDEN, M. (2010). The role of urgency and its underlying psychological mechanisms in problematic behaviours. Behaviour Research and Therapy, 48, 1085-1096.

BILLIEUX, J., ROCHAT, L., REBETEZ, M. M. L. \& VAN DER LINDEN, M. (2008). Are all facets of impulsivity related to self-reported compulsive buying behavior? Personality and Individual Differences, 44, 1432-1442.

BILLIEUX, J., VAN DER LINDEN, M. \& CESCHI, G. (2007). Which dimensions of impulsivity are related to cigarette craving? Addictive Behaviors, 32, 1189-1199.

BRISLIN, R. W. (1970). Back-Translation for Cross-Cultural Research. Journal of CrossCultural Psychology, 1, 185-216.

BUSS, D. M. (1991). Evolutionary Personality Psychology. Annual Review of Psychology, 42, 459-491.

CHAPMAN, D. W. \& CARTER, J.F. (1979). Translation procedures for the cross cultural use of measurement instruments. Education Evaluation and Policy Analysis, 1(3): 7176.

COBB, C. J. \& HOYER, W. B. (1986). Planned Versus Impulse Purchase Behavior. Journal of Retailing, 62, 384.

COLEY, A. \& BURGESS, B. (2003). Gender differences in cognitive and affective impulse buying. Journal of Fashion Marketing and Management, 7, 282-295. 
CRAWFORD, G. \& MELEWAR, T. C. (2003). The importance of impulse purchasing behaviour in the international airport environment. Journal of Consumer Behaviour, 3, 85-98.

DICKMAN, S. (1990). Functional and dysfunctional impulsivity: personality and cognitive correlates. Journal of Personality and Social Psychology, 58, 95-102.

DITTMAR, H., BEATTIE, J. \& FRIESE, S. (1995). Gender identity and material symbols: Objects and decision considerations in impulse purchases. Journal of Economic Psychology, 16, 491-511.

DITTMAR, H. \& BOND, R. (2010). I want it and I want it now: Using a temporal discounting paradigm to examine predictors of consumer impulsivity. British Journal of Psychology, 101, 751-776.

DORAN, K. (2002). Lessons learned in cross-cultural research of Chinese and North American consumers. Journal of Business Research, 55, 823-829.

EVENDEN, J. L. (1999). Varieties of impulsivity. Psychopharmacology, 146, 348-361.

FISCHER, E. \& ARNOLD, S. J. (1994). Sex, gender identity, gender role attitudes, and consumer behavior. Psychology and Marketing, 11, 163-182.

FOXALL, G. \& GREENLEY, G. (1999). The Affective Structure of Consumer Situations. Environment and Behavior, 30, 781-798.

FOXALL, G. R. \& YANI-DE-SORIANO, M. M. (2005). Situational influences on consumers' attitudes and behavior. Journal of Business Research, 58, 518-525.

HERABADI, A. G., VERPLANKEN, B. \& VAN KNIPPENBERG, A. (2009). Consumption experience of impulse buying in Indonesia: Emotional arousal and hedonistic considerations. Asian Journal of Social Psychology, 12, 20-31.

HOCH, S. J. \& LOEWENSTEIN, G. F. (1991). Time-Inconsistent Preferences and Consumer Self-Control. Journal of Consumer Research, 17, 492-507.

HOFSTEDE, G. (1998). Identifying Organizational Subcultures: An Empirical Approach. Journal of Management Studies, 35, 1-12.

HOFSTEDE, G. \& BOND, M. H. (1984). Hofstede's Culture Dimensions. Journal of Cross-Cultural Psychology, 15, 417-433.

HOFSTEDE, G. \& MCCRAE, R. R. (2004). Personality and Culture Revisited: Linking Traits and Dimensions of Culture. Cross-Cultural Research, 38, 52-88.

HOWITT, D. and CRAMER, D. (2008). Introduction to SPSS in Psyhchology For version 16 and earlier, 4th Edition, Gosport, Pearson Education.

JONES, M. A., REYNOLDS, K. E., WEUN, S. \& BEATTY, S. E. (2003). The productspecific nature of impulse buying tendency. Journal of Business Research, 56, 505511.

KACEN, J. J. \& LEE, J. A. (2002). The Influence of Culture on Consumer Impulsive Buying Behavior. Journal of Consumer Psychology (Lawrence Erlbaum Associates), 12, 163-176.

KEYE, D., WILHELM, O. \& OBERAUER, K. (2009). Structure and Correlates of the German Version of the Brief UPPS Impulsive Behavior Scales. European Journal of Psychological Assessment, 25, 175-185.

KOLLAT, D. T. \& WILLETT, R. P. (1967). Customer Impulse Purchasing Behavior. Journal of Marketing Research, 4, 21-31. 
LEE, J. A. \& KACEN, J. J. (2008). Cultural influences on consumer satisfaction with impulse and planned purchase decisions. Journal of Business Research, 61, 265-272.

LUCAS, R.E., DIENER, E., GROB A., SUH EM, S. L. (2000). Cross-cultural evidence for the fundamental features of extraversion . Journal of Personality and Social. Psychology. 79:452-68

MAGID, V. \& COLDER, C. R. (2007). The UPPS Impulsive Behavior Scale: Factor structure and associations with college drinking. Personality and Individual Differences, 43, 1927-1937.

MAI, N. T. T., KWON, J., LANTZ, G. \& LOEB, S. G. (2003). An Exploratory Investigation into Impulse Buying Behavior in a Transitional Economy: A Study of Urban Consumers in Vietnam. Journal of International Marketing, 11, 13-35.

PHAU \& LO, C. C. (2004). Profiling fashion innovators: A study of self-concept, impulse buying and Internet purchase intent. Journal of Fashion Marketing \& Management, 8, 399-411.

PIRON, F. (1991). Defining Impulse Purchasing. Advances in Consumer Research, 18, 509-514.

PUNJ, G. (2011). Impulse buying and variety seeking: Similarities and differences. Journal of Business Research, 64, 745-748.

PURI R. (1996), Measuring and modifying consumer impulsiveness: a cost-benefit accessibility framework. Journal of Consumer Psychology, 5(2),87-113.

ROOK, D. W. (1987). The Buying Impulse. Journal of Consumer Research, 14, 189-199.

ROOK, D. W. \& FISHER, R. J. (1995). Normative Influences on Impulsive Buying Behavior. Journal of Consumer Research, 22, 305-313.

ROOK, D. W. \& HOCH, S. J. (1985). CONSUMING IMPULSES. Advances in Consumer Research, 12, 23-27.

ROTH, M., HAMMELSTEIN, P. \& BR HLER, E. (2007). Beyond a youthful behavior style - Age and sex differences in sensation seeking based on need theory. Personality and Individual Differences, 43, 1839-1850.

SHARMA, P., SIVAKUMARAN, B. \& MARSHALL, R. (2010). Impulse buying and variety seeking: A trait-correlates perspective. Journal of Business Research, 63, 276283.

SILVERA, D. H., LAVACK, A. M. \& KROPP, F. (2008). Impulse buying: the role of affect, social influence, and subjective wellbeing. Journal of Consumer Marketing, 25, 23-33.

SPECTOR, P. E., COOPER, C. L. \& SPARKS, K. (2001). An International Study of the Psychometric Properties of the Hofstede Values Survey Module 1994: A Comparison of Individual and Country/Province Level Results. Applied Psychology, 50, 269-281.

STEINBERG, L., ALBERT, D., CAUFFMAN, E., BANICH, M., GRAHAM, S. \& WOOLARD, J. (2008). Age Differences in Sensation Seeking and Impulsivity as Indexed by Behavior and Self-Report: Evidence for a Dual Systems Model. Developmental Psychology, 44, 1764-1778.

VERPLANKEN, B. \& HERABADI, A. (2001). Individual differences in impulse buying tendency: feeling and no thinking. European Journal of Personality, 15, S71-S83.

VERPLANKEN, B. \& SATO, A. (2011). The Psychology of Impulse Buying: An Integrative Self-Regulation Approach. Journal of Consumer Policy, 34, 197-210. 
VOHS, K. D. \& FABER, R. J. (2007). Spent Resources: Self - Regulatory Resource Availability Affects Impulse Buying. Journal of Consumer Research, 33, 537-547.

WEUN, S., JONES, M. A. \& BEATTY, S. E. (1998). Development and Validation of The Impulse Buying Tendency Scale. Psychological Reports, 82, 1123-1133.

WHITESIDE, S. P. \& LYNAM, D. R. (2001). The Five Factor Model and impulsivity: using a structural model of personality to understand impulsivity. Personality and Individual Differences, 30, 669-689.

WILLIAMS, D. G. (1982). Relationships between the Bem sex-role inventory and the Eysenck Personality Questionnaire. Personality and Individual Differences, 3, 223224.

WOOD, M. (1998). Socio-economic status, delay of gratification, and impulse buying. Journal of Economic Psychology, 19, 295-320.

XIAO, S. H. \& NICHOLSON, M. (2011). Mapping impulse buying: a behaviour analysis framework for services marketing and consumer research. The Service Industries Journal, 31, 2515-2528.

XIAO, S. H. \& NICHOLSON, M. (2012). A Multidisciplinary Cognitive Behavioural Framework of Impulse Buying: A Systematic Review of the Literature. International Journal of Management Reviews, 1-24

YOUN, S. \& FABER, R. J. (2000). Impulse Buying: Its Relation to Personality Traits and Cues. Advances in Consumer Research, 27, 179-185.

YU, C. \& BASTIN, M. (2010). Hedonic shopping value and impulse buying behavior in transitional economies: A symbiosis in the Mainland China marketplace. Journal of Brand Management, 18, 105-114.

ZHOU, L. \& WONG, A. (2004). Consumer Impulse Buying and In-Store Stimuli in Chinese Supermarkets. Journal of International Consumer Marketing, 16, 37-53.

ZUCKERMAN, M. \& KUHLMAN, D. M. (2000). Personality and Risk-Taking: Common Bisocial Factors. Journal of Personality, 68, 999-1029.

Notes:

This study is one part of a $\mathrm{PhD}$ thesis submitted in fulfillment of the requirements for the degree of Doctor of Philosophy of Durham University, UK. 
TABLES AND FIGURES

Table 1 Sample Distribution

\begin{tabular}{|c|c|c|c|c|c|c|c|}
\hline \multirow{2}{*}{\multicolumn{3}{|c|}{\begin{tabular}{|l} 
NATIONAL \\
NATIOL
\end{tabular}}} & \multicolumn{4}{|l|}{ AGE } & \multirow[b]{2}{*}{ Total } \\
\hline & & & $18-25$ & 25-35 & $35-50$ & OVER50 & \\
\hline \multirow[t]{3}{*}{ BRITISH } & SEX & MAN & 35 & 15 & 22 & 23 & 95 \\
\hline & & WOMAN & 32 & 19 & 24 & 31 & 106 \\
\hline & Total & & 67 & 34 & 46 & 54 & 201 \\
\hline \multirow[t]{3}{*}{ TAIWAN } & SEX & MAN & 10 & 37 & 23 & 18 & 88 \\
\hline & & WOMAN & 16 & 60 & 37 & 10 & 123 \\
\hline & Total & & 26 & 97 & 60 & 28 & 211 \\
\hline
\end{tabular}

Table 2 The BPM Matrix and the Scenarios' Design

\begin{tabular}{|l|l|}
\hline $\begin{array}{l}\text { Greenley \& } \\
\text { Foxall (1999) }\end{array}$ & The Present Study \\
\hline $\begin{array}{l}\text { Luxury } \\
\text { shopping }\end{array}$ & $\begin{array}{l}\text { Luxury shopping in Harrods- } \\
\text { You are browsing some luxury products such as Gucci or Prada at Harrods } \\
\text { with your friends. You know that buying luxury products is a way to treat } \\
\text { yourself well and your friends would admire it too. Would you impulse buy } \\
\text { something now? }\end{array}$ \\
\hline $\begin{array}{l}\text { Gambling in a } \\
\text { casino }\end{array}$ & $\begin{array}{l}\text { High-end dining in a restaurant- } \\
\text { You are dining in a high-end restaurant where has exclusive atmosphere and } \\
\text { you see people around you enjoying their dessert or drink. Even after main } \\
\text { course you are a bit full, would you order more dessert or drink? }\end{array}$ \\
\hline Watching TV & $\begin{array}{l}\text { Day out shopping with family/friends- } \\
\text { You and friends/family are having a day-out for shopping. Would you buy } \\
\text { something on impulse? }\end{array}$ \\
\hline entertainment & $\begin{array}{l}\text { Having to accompany someone to the shops- } \\
\text { You have to accompany someone to a department store even though you } \\
\text { didn't plan to buy anything today. Is it likely that you end up buying } \\
\text { something anyway? }\end{array}$ \\
\hline Saving & $\begin{array}{l}\text { Finding an item that complete the collection- } \\
\text { You have one thing short to complete your collection (Ex: Stamps, coins, or } \\
\text { sport cards) one day you suddenly found this item, although it might be } \\
\text { expensive and you are running out of money, would you get it anyway? }\end{array}$ \\
\hline $\begin{array}{l}\text { Fredit card point scheme- } \\
\text { Your credit card company now offers you several items this month to confer }\end{array}$ \\
\hline
\end{tabular}




\begin{tabular}{|l|l|}
\hline & $\begin{array}{l}\text { your credit points, although you know waiting longer and saving more points } \\
\text { can get you a bigger reward (Ex: a flight ticket), would you spend your points } \\
\text { now? }\end{array}$ \\
\hline $\begin{array}{l}\text { Grocery } \\
\text { shopping }\end{array}$ & $\begin{array}{l}\text { Routine shopping at a supermarket- } \\
\text { You are doing your routine food shopping in the supermarket and you see } \\
\text { something you like or on sale but was not on your original shopping list. } \\
\text { Would you buy it on impulse? }\end{array}$ \\
\hline Paying taxes & $\begin{array}{l}\text { Last call of the bar- } \\
\text { You and your friends are at a bar and it is about to close. The bar is ringing } \\
\text { the bell for "the last order", would you buy another drink after you heard the } \\
\text { last call? }\end{array}$ \\
\hline
\end{tabular}

Table 3 Cross-tabulation on Impulse Buying Choice and Nationality

\begin{tabular}{|c|c|c|c|c|}
\hline \multicolumn{2}{|l|}{ Situation } & British & Taiwanese & Significance \\
\hline \multirow[t]{2}{*}{ Shopping at Harrods } & Yes & 38 & 23 & \\
\hline & No & 163 & 190 & $\mathrm{p}<0.05$ \\
\hline \multirow[t]{2}{*}{ High End Dining } & Yes & 57 & 98 & \\
\hline & No & 144 & 115 & $\mathrm{p}<0.05$ \\
\hline \multirow[t]{2}{*}{ Day-out Shopping } & Yes & 177 & 137 & \\
\hline & No & 24 & 76 & $\mathrm{p}<0.05$ \\
\hline \multirow[t]{2}{*}{ Inescapable Shopping } & Yes & 87 & 132 & \\
\hline & No & 114 & 81 & $\mathrm{p}<0.05$ \\
\hline \multirow{2}{*}{ Credit card reward } & Yes & 13 & 18 & \\
\hline & No & 188 & 195 & $\mathrm{p}>0.05$ \\
\hline \multirow[t]{2}{*}{ Private collection } & Yes & 117 & 103 & \\
\hline & No & 84 & 110 & $\mathrm{p}<0.05$ \\
\hline \multirow[t]{2}{*}{ Bar last call } & Yes & 123 & 35 & \\
\hline & No & 78 & 178 & $\mathrm{p}<0.05$ \\
\hline \multirow[t]{2}{*}{ Routine Shopping } & Yes & 196 & 194 & \\
\hline & No & 5 & 19 & $\mathrm{p}<0.05$ \\
\hline
\end{tabular}


Table 4: Mann-Whitney test on UPPS and IB Tendency

\begin{tabular}{|c|c|c|c|c|c|}
\hline & & Ranks & & & \\
\hline & NATIONAL & $\mathrm{N}$ & Mean Rank & Sum of Ranks & Significance \\
\hline \multirow[t]{3}{*}{ PRETOTAL } & BRITISH & 201 & 191.05 & 38400.5 & \\
\hline & TAIWANESE & 213 & 223.03 & 47504.5 & $\mathrm{p}<0.05$ \\
\hline & Total & 414 & & & \\
\hline \multirow[t]{3}{*}{ UTOTAL } & BRITISH & 201 & 209.83 & 42175.5 & \\
\hline & TAIWANESE & 213 & 205.3 & 43729.5 & $\mathrm{p}>0.05$ \\
\hline & Total & 414 & & & \\
\hline \multirow[t]{3}{*}{ SENTOTAL } & BRITISH & 201 & 232.87 & 46806 & \\
\hline & TAIWANESE & 213 & 183.56 & 39099 & $\mathrm{p}<0.05$ \\
\hline & Total & 414 & & & \\
\hline \multirow[t]{3}{*}{ PERTOTAL } & BRITISH & 201 & 217.81 & 43779 & \\
\hline & TAIWANESE & 213 & 197.77 & 42126 & $p>0.05$ \\
\hline & Total & 414 & & & \\
\hline \multirow[t]{3}{*}{ IBTOTAL } & BRITISH & 201 & 226.36 & 45499 & \\
\hline & TAIWANESE & 213 & 189.7 & 40406 & $\mathrm{p}<0.05$ \\
\hline & Total & 414 & & & \\
\hline
\end{tabular}

Table 5: The Results of Significant Predictors of the Impulse Buying Choice Situation Predictors

\begin{tabular}{|l|l|}
\hline Shopping at Harrods & Culture is close to significant ( $\mathrm{p}=0.051)$ \\
\hline High-end Dining & Premeditation, culture (Taiwanese) \\
\hline Day-out Shopping & Impulse buying tendency, culture (British) \\
\hline Inescapable Shopping & Impulse buying tendency, culture (Taiwanese) \\
\hline Private Collection & Impulse buying tendency, sensation seeking \\
\hline Credit Card Reward & n/a \\
\hline Routine Shopping & Impulse buying tendency, culture (British) \\
\hline Bar Last Call & Culture (British), sensation seeking \\
\hline
\end{tabular}

